\title{
A scientific note on the behavior of the endangered Anthricinan yellow-faced bee (Hylaeus anthracinus) from South Kohala District, Hawai'i, Hawai'i
}

\author{
Aaron D. PAN ${ }^{1}$, Joseph S. WILSON ${ }^{2}$ \\ ${ }^{1}$ Don Harrington Discovery Center, 1200 Streit Drive, Amarillo, TX 79106, USA \\ ${ }^{2}$ Department of Biology, Utah State University Tooele, Tooele, UT 84074, USA
}

Received 10 July 2019 - Revised 9 October 2019 - Accepted 13 January 2020

aggression / behavior / display / endangered / Hawaii / Hawaiian yellow-faced bees / Hylaeus

On September 30, 2016, seven endemic species of Hawaiian yellow-faced bees (Colletidae), Hylaeus anthracinus (F. Smith 1853), H. assimulans (Perkins 1899), H. facilis (F. Smith 1879), H. hilaris (F. Smith 1879), H. kuakea Magnacca \& Daly 2003, H. longiceps (Perkins 1899), and H. mana Magnacca \& Daly 2003, were listed in the Federal Register to become the first bees included on the US Fish and Wildlife Service Federal Lists of Endangered and Threatened Wildlife and Plants (US Fish and Wildlife Service 2016). Hylaeus anthracinus, the Anthricinan yellow-faced bee, a coastal and lowland bee endemic to the Hawaiian Islands is one of the more geographically widespread species listed, being found on the islands of Hawai' $\mathrm{i}, \mathrm{Ka}$ ho'olawe, Mau'i, Moloka'i, O'ahu, and historically on Lāna'i (Daly and Magnacca 2003; Magnacca 2007). This species' range and population have dramatically decreased in recent years due to coastal

Electronic supplementary material The online version of this article (https://doi.org/10.1007/s13592-020-00734-9) contains supplementary material, which is available to authorized users.

Corresponding author: A. Pan, apan@dhdc.orgD. Pan, apan@dhdc.org

Manuscript editor: Bernd Grünewald development (Magnacca 2007; Magnacca and King 2013). However, a relatively large population has been reported in the North Kona-Kohala region, although it occurs where several resorts, recreational areas, and residential development exist (Magnacca and King 2013).

Few observation reports of behavior within the genus Hylaeus are known (but see Batra 1978 and Alcock and Houston 1987), including the Hawaiian taxa. However, to facilitate conservation of these federally listed endangered species, it will be necessary to better understand their behavior and more details of their ecological requirements and interactions (Afonso et al. 2008; Alberts 2007). This scientific note is provided to contribute additional information as to the behavior of Hylaeus anthracinus .

The study site represents littoral coastal habitat located between Holoholokai Beach Park and the Pauoa Beach Club in South Kohala District of Hawai'i, Hawai'i. The site consists of beach vegetation dominated by Heliotropium foertherianum Diane \& Hilger 2003 and Scaevola taccada (Gaertn.) Roxb. 1814 growing next to coral rubble, basalt, and calcareous (sea-shell derived) and olivine-rich basalt beach sand and gravel (Figure 1a). Observations were made daily between 
0530 and $1500 \mathrm{~h}$ Hawaii-Aleutian Standard Time (HAST), June 23-27, 2019 at least 3 times each day.

Male Hylaeus anthracinus can be easily identified based on the presence of a large, single yellow-marking on the face that extends up to the base of the antennal sockets (Daly and Magnacca 2003). The observed males do not represent Hylaeus flavipes (F. Smith 1853), the only other known coastal Hylaeus species that occurs on the island of Hawai' $i$, since the yellow facial markings do not extend along the margin of the eye past the antennal sockets, which is characteristics for H. flavipes (Daly and Magnacca 2003).
The Hylaeus females also likely represent Hylaeus anthracinus due to a previous report of this species presence at this locality and the only known coastal population of Hylaeus flavipes on Hawai'i occurs much further south at South Point (Magnacca and King 2013).

Males display aggression, actions that could or have the potential to cause harm or have negative effects on a rival, and what appears to be short-term territoriality by defending males towards patrolling males after finding prominent areas on the adaxial surface, leaf margin, or rarely prominently exposed abaxial surfaces of Heliotropium foertherianum
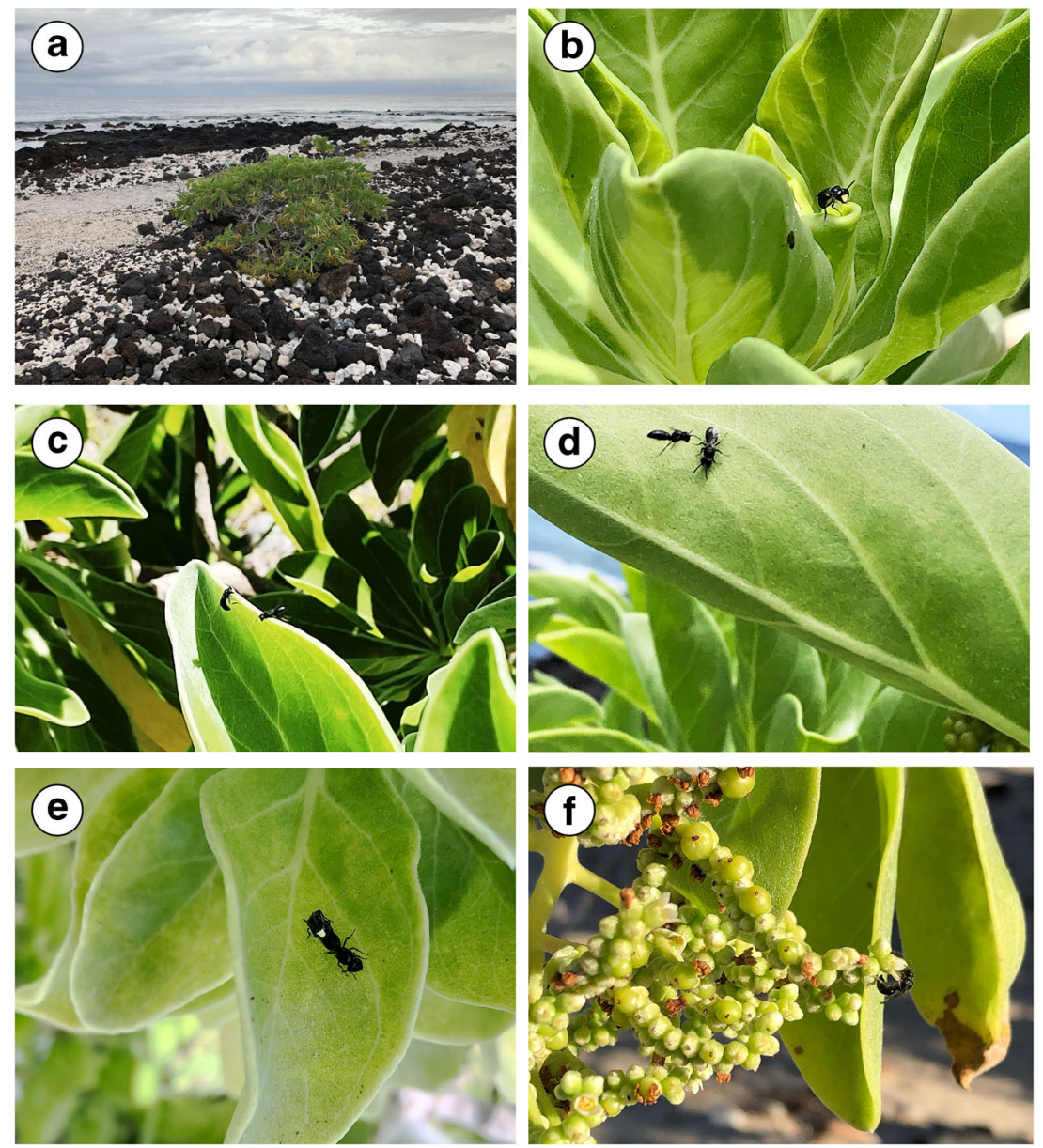

Figure 1. Hylaeus anthracinus and habitat. a Littoral habitat consisting of basalt, coral rubble, and beach vegetation including Heliotropium foertherianum. b Male H. anthracinus defending position on leaf tip. c Defending male H. anthracinus directing head towards patrolling male. d Patrolling male $H$. anthracinus attempting to displace defending male. e Mating H. anthracinus . f Female H. anthracinus feeding or collecting pollen from Heliotropium foertherianum flower. 
leaves to display (Figure 1b). Display behaviors consist of antennal grooming and vibrating their abdomens and wings. Males that gain a prominent position on the leaf appear to defend their position by rotating their body to have their face directed at other males that fly towards them (Figure 1c). Flying (patrolling) males try to displace the defending male's position on the leaf by pushing or ramming the defending male off balance often from the side (Figure 1d). Patrolling males attempting to displace the defending male often abort attempts when the defending male orients its face directly at the approaching male. In several cases, approaching patrolling males that came in close proximity to the defending male would be chased/pursued/rammed by the defending male, which would often temporarily abandon their leaf position. Defending males appear to favor leaves surrounding new budding flower inflorescences. Patrolling males were also found flying over inflorescences of the Heliotropium .

In addition to male behaviors on Heliotropium, defending males were also observed defending pieces of coral rubble in a similar manner to that observed of males displaying on the plants. In addition, males were seen flying and following females over coral rubble areas. Females flew low over the ground, landed, and often searched holes and cavities in the coral, presumably for potential brood sites. Cavities within coral rubble are often used as brooding chambers for Hylaeus anthracinus (Graham 2015).

Males did not appear to show aggressive behavior towards any other species present on plant parts of Heliotropium foertherianum, including dolichopodid flies on leaves and non-native bee taxa individuals of Apis, Ceratina, Lasioglossum, and Xylocopa feeding and/or collecting pollen from the flowers.

Males were observed mating or attempting to mate with females while the females fed on nectar and/or were collecting pollen on Heliotropium foertherianum flowers. Males were also observed mating with females on the adaxial surfaces of Heliotropium leaves (Figure 1e). In addition, males attempting to mate were often rejected by females. Females would fend off mating advances using their hind legs to push the males off of them. Females were also observed rejecting secondary and tertiary males after what appears to have been successful mating/copulation with a single male, again using their hind legs to push off the secondary or tertiary male. While it is possible that the female Hylaeus that rejected male mating attempts could represent a different species, $H$. flavipes, this is unlikely since the only known population of coastal $H$. flavipes on Hawai' $i$ occurs at South Point and only $H$. anthracinus has been reported from coastal North Kona-Kohala (Magnacca and King 2013).

Hylaeus anthracinus individuals were mainly observed flying, feeding, resting, mating, and showing territorial/aggressive behavior towards each other on Heliotropium foertherianum, particularly plants that were just above or growing on coral rubble or growing on the beach (Figure 1ae). A few individual bees were found flying low over flowering plants of Scaevola taccada .

Aggression and territorial behavior have been reported in a Western Australian species, Hylaeus alcyoneus (Erichson 1842) (Alcock and Houston 1987). While male-male aggression was found in our observations, $H$. anthracinus does not appear to maintain territorial claim fidelity on leaves for long periods of time like H. alcyoneus on Banksia inflorescences (Alcock and Houston 1987).

It is notable about the observation that defending Hylaeus anthracinus males may ward off rivals by directly orienting their head in the direction of the individual. The presence of distinctive and diagnostic yellow or white markings on the faces of many Hylaeus species in the genus suggests an adaptation, possibly to use in aggressive activities against rivals while in competition for resources or mates, particularly amongst males. In addition, markings on the head of Hylaeus species may be used to attract mates and to recognize conspecifics.

Heliotropium foertherianum, a non-native coastal tree from the Indo-West Pacific (McDermid et al. 2018), appears to represent an important food resource for Hylaeus anthracinus and has been reported as such in Daly and Magnacca (2003), Magnacca (2007), and Magnacca and King (2013). In addition, based on our observations, the individual plants of this species may play an important role in mating and competitive behavior within species. Interestingly, 
few Hylaeus individuals were found patrolling over or feeding/collecting pollen from Scaevola taccada, which represents a ubiquitous indigenous plant to these littoral coastal communities. Any conservation plans focused on increasing the range and population size of Hylaeus anthracinus needs to insure that Heliotropium foertherianum is an available resource, as noted in Magnacca and King (2013), particularly small, but mature plants that range in size from 1 to $3 \mathrm{~m}$ in height.

Currently, the South Kohala population appears to be stable even with its close proximity to development (resorts, golf courses, and residences), likely due to the presence of protected green sea turtle (Chelonia mydas Linnaeus 1758) habitat in the littoral zone and the close proximity of Holoholokai Beach Park and Puakō Petroglyph Park; all of which minimize disturbance. Additional protection of the coral rubble areas near the Mauna Lani Golf Course and the small to medium-sized Heliotropium plants (1-3 m) that are in the littoral zone would assist this population, as well as the possible cultivation of Sida fallax Walp. 1843 (Daly and Magnacca 2003).

\section{AUTHORS' CONTRIBUTIONS}

ADP and JSW conceived research; ADP and JSW participated in the design and interpretation of data; ADP collected data; ADP and JSW wrote the paper. All authors read and approved the final manuscript.

\footnotetext{
Note scientifique sur le comportement d'une espèce menacée l'abeille Hylaeus anthracinus du district de South Kohala, Hawaii, Hawaii.
}

agression / comportement / en voie de disparition / abeilles hawaïennes à face jaune.

Eine wissenschaftliche Notiz zum Verhalten der gefährdeten Hylaeus anthracinus Biene aus dem South Kohala District, Hawaii, Hawaii.
Aggression / Verhalten / gefährdet / Hawaiianische Gelbmaskenbienen.

\section{REFERENCES}

Afonso P, Fontes J, Holland KN, Santos RS (2008) Social status determines behavior and habitat usage in a temperate parrotfish: implications for marine reserve design. Mar. Ecol. Prog. Ser. 359: 215-227.

Alberts AC (2007) Behavioral considerations of headstarting as a conservation strategy for endangered Caribbean rock iguanas. Appl. Anim. Behav. Sci. 102: 380-391.

Alcock J, Houston TF (1987) Resource defense and alternative mating tactics in the Banksia Bee, Hylaeus alconeus (Erichson). Ethol. 76: 177-188.

Batra SWT (1978) Aggression, territoriality, mating and nest aggregation of some solitary bees (Hymenoptera: Halictidae, Megachilidae, Colletidae, Anthophoridae). J. Kans. Entomol. Soc. 51: 547-559.

Daly HV, Magnacca KN (2003) Insects of Hawaii, Volume 17: Hawaiian Hylaeus (Nesoprosopis) bees (Hymenoptera: Apoidea). University of Hawai'i Press, Honolulu.

Graham JR (2015) The nest architecture of Hylaeus anthracinus and other coastal solitary bees. $23^{\text {rd }}$ Annual Hawai'i Conservation Conference, Hilo, Hawai'I, August 3-6, 2015.

Magnacca KN (2007) Conservation status of the endemic bees of Hawai'i, Hylaeus (Nesoprosopis) (Hymenoptera: Colletidae). Pac. Sci. 61: 173-190.

Magnacca KN, King CBA (2013) Assessing the presence and distribution of 23 Hawaiian yellow-faced bee species on lands adjacent to military installations on O'ahu and Hawai'i Island. Technical Report No. 185. Pacific Cooperative Studies Unit, University of Hawai'i, Honolulu, Hawai'i. 39 pp

McDermid KJ, Jha R, Rice MR, Balazs GH (2018) Of turtles and trees: nutritional analysis of tree heliotrope (Heliotropium foertherianum) leaves consumed by green turtles (Chelonia mydas) in Hawai'i. Micronesica 2018-02: 1-11.

US Fish and Wildlife Service (2016) Endangered and Threatened Wildlife and Plants; Endangered Status for 49 Species from the Hawaiian Islands - Final Rule - FWS-R1-ES-2015-0125; 4500030113. Federal Register 81(190): 1-75.

Publisher's note Springer Nature remains neutral with regard to jurisdictional claims in published maps and institutional affiliations. 